\title{
PENERAPAN MODEL PEMBELAJARAN CREATIVE PROBLEM SOLVING (CPS) UNTUK MENINGKATKAN KEMAMPUAN PEMECAHAN MASALAH MAHASISWA PENDIDIKAN MATEMATIKA
}

\section{IMPLEMENTATION OF CREATIVE PROBLEM SOLVING (CPS) LEARNING MODEL TO INCREASE PROBLEM SOLVING SKILLS OF MATHEMATICS EDUCATION STUDENTS}

\author{
Muhammad Turmuzi, Sripatmi, Syahrul Azmi, Nurul Hikmah \\ Program Studi Pendidikan Matematika Jurusan Pendidikan MIPA Fakultas Keguruan dan Ilmu Pendidikan, \\ Universitas Mataram. Jalan Majapahit No. 62 Mataram, Lombok, 83125, Indonesia \\ Email: tur.muzi@yahoo.co.id
}

Diterima: 15 Desember 2017. Disetujui: 24 Maret 2018. Dipublikasikan: 31 Maret 2018

\begin{abstract}
Abstrak: Tujuan penelitian ini adalah untuk meningkatkan kemampuan pemecahan masalah mahasiswa Pendidikan Matematika Fakultas Keguruan dan Ilmu Pendidikan Universitas Mataram melalui model pembelajaran Creative Problem Solving (CPS) pada mata kuliah Analisis Kompleks. Penelitian ini menggunakan pendekatan penelitian tindakan kelas yang terdiri dari beberapa tahapan, yaitu: perencanaan, tindakan, observasi, dan refleksi. Tahap perencanaan terdiri dari kegiatan penyusunan rencana pembelajaran, instrumen penelitian, pada tahap tindakan meliputi kegiatan pemberian tindakan berupa pembelajaran sesuai dengan rancangan pembelajaran yang telah dibentuk sesuai dengan prinsip-prinsip pembelajaran Creative Problem Solving (CPS), tahap observasi meliputi kegiatan observasi terhadap aktivitas mahasiwa selama pembelajaran, khususnya pada saat diskusi dan keterlaksanaan tindakan serta hambatan-hambatan yang ditemui, dan tahap refleksi merupakan kegiatan refleksi terhadap pelaksanaan pembelajaran berdasarkan hasil observasi dan hasil penilain kemampuan pemecahan masalah. Hal-hal yang menjadi perhatian pada tahap refleksi ini adalah penilaian terhadap keterlaksanaan tindakan, hambatan-hambatan yang muncul, serta kemajuan-kemajuan yang telah dicapai. Untuk memperoleh data penelitian digunakan dua jenis instrumen penelitian yaitu lembar observasi pelaksanaan pembelajaran dan pedoman observasi serta soal tes kemampuan pemecahan masalah. Hasil penelitian ini menunjukkan bahwa rata-rata kemampuan pemecahan masalah mahasiswa pada siklus I adalah sebesar 68,56 meningkat menjadi 83,00 pada siklus II. Rata-rata peningkatan kemampuan pemecahan masalah adalah sebesar $21,06 \%$.
\end{abstract}

Kata Kunci: Pemecahan masalah, Creative Problem Solving

Abstract: The purpose of this study is to improve the problem solving skills of Mathematics Education students Fakulty of Teacher Training and Education University of Mataram through Creative Problem Solving (CPS) learning model in Complex Analysis course. This study uses a classroom action research approach. Each cycle consists of several stages: planning, action, observation, and reflection. At the planning stage consists of the activities of the preparation of the lesson plans, the preparation of research instruments, the action stage includes activities in the form of teaching activities in accordance with the design of learning that has been formed in accordance with the principles of learning Creative Problem Solving (CPS), the observation stage includes activity observation of activity students during the lesson, especially during the discussion and implementation of the actions and obstacles encountered, and the reflection stage is a reflection of the implementation of learning based on the results of observation and the results of assessment of problem-solving skills. Matters of concern at this stage of reflection are an assessment of the implementation of actions, constraints arising, and the progress that has been achieved. Two types of research instruments were applied to obtain research data. The research instruments are observation sheets of instructional implementation and observation guidance as well as test problem solving abilities. The results of this study indicate that the average ability of problem solving students in cycle I is equal to 68.56 increased to 83.00 in cycle II. The average increase in problem solving ability is $21.06 \%$.

Keywords: Problem solving, Creative Problem Solving

\section{PENDAHULUAN}

Kemampuan pemecahan masalah adalah suatu keterampilan pada diri mahasiswa agar mampu menggunakan kegiatan matematis untuk memecahkan masalah dalam matematika, masalah dalam ilmu lain dan masalah dalam kehidupan sehari-hari [1,2]. Kemampuan pemecahan masalah dapat juga diartikan sebagai kapasitas seorang mahasiswa dalam usaha menyelesaikan suatu permasalahan dengan memanfaatkan segala pengetahuan yang dimiliki. Pemecahan masalah 
adalah suatu proses terencana yang perlu dilaksanakan agar memperoleh penyelesaian tertentu dari sebuah masalah yang mungkin tidak didapat dengan segera [3]. Pendapat lainnya menyatakan bahwa pemecahan masalah sebagai usaha mencari jalan keluar dari suatu kesulitan [4]. Aspek-aspek berikut perlu diperhatikan ketika mengecek kembali langkah-langkah yang sebelumnya terlibat dalam menyelesaikan masalah, yaitu: (1) mengecek kembali semua informasi yang penting yang telah teridentifikasi; (2) mengecek semua perhitungan yang sudah terlibat; (3) mempertimbangkan apakah solusinya logis; (4) melihat alternatif penyelesaian yang lain; dan (5) membaca pertanyaan kembali dan bertanya kepada diri sendiri apakah pertanyaannya sudah benar-benar terjawab.

Selama ini pembelajaran matematika terkesan kurang menyentuh kepada substansi pemecahan masalah. Mahasiswa cenderung menghafalkan kosep-konsep matematika sehingga kemampuan mahasiswa dalam memecahkan masalah sangat kurang. Pemecahan masalah merupakan bagian dari kurikulum matematika yang sangat penting karena dalam proses pembelajaran maupun penyelesaiannya, mahasiswa dimungkinkan memperoleh pengalaman menggunakan pengetahuan serta keterampilan yang sudah dimiliki untuk diterapkan pada pemecahan masalah. Pemecahan masalah matematika merupakan salah satu kegiatan matematika yang dianggap penting di semua tingkatan mulai dari SD sampai SMU. Namun hal tersebut dianggap bagian yang paling sulit dalam mempelajarinya maupun bagi dosen dalam mengajarkannya. Suatu masalah biasanya memuat suatu situasi yang mendorong seseorang untuk menyelesaikannya, akan tetapi tidak tahu secara langsung apa yang harus dikerjakan untuk menyelesaikannya.

Salah satu cara yang dapat meningkatkan kemampuan pemecahan masalah mahasiswa adalah dengan penerapan Model Pembelajaran Creative Problem Solving (CPS). pembelajaran Creative Problem Solving (CPS) adalah suatu metode pembelajaran yang melakukan pemusatan pada pengajaran dan ketrampilan memecahkan masalah, yang diikuti dengan penguatan keterampilan. Ketika dihadapkan dengan suatu pertanyaan/permasalahan, mahasiswa dapat melakukan ketrampilan memecahkan masalah untuk memilih dan mengembangkan tanggapannya. Tidak hanya dengan cara menghafal tanpa dipikir, keterampilan memecahkan masalah memperluas proses berpikir $[5,6]$.

Berdasarkan latar belakang dan permasalahan dalam penelitian maka peneliti tertarik untuk melakukan penelitian dengan judul upaya meningkatkan kemampuan pemecahan masalah mahasiswa pendidikan matematika fkip unram melalui model pembelajaran Creative Problem Solving $(C P S)$ pada mata kuliah analisis kompleks. Pada penelitian ini indikator yang digunakan untuk menunjukkan seorang mahasiswa telah mempunyai kemampuan pemecahan masalah adalah (1) Memahami masalah yang ada Mahasiswa memahami masalah yang dihadapi sehingga dapat menentukan data apa saja yang diketahui dan apa yang ditanyakan (apa yang harus ditentukan solusinya) (2).Menentukan strategi penyelesaian yang tepat: Mahasiswa dapat menemukan hubungan antara data yang diketahui dengan apa yang ditanyakan. Kemudian memilih atau mengkombinasikan teorema-teorema atau konsepkonsep yang telah dipelajari sehingga dapatdigunakan untuk menyelesaikan masalah tersebut. Pada akhir langkah ini harus tersusun sebuah strategi untuk menentukansolusidari permasalahan. (3). Melaksanakan strategi yang telah dipilih Melaksanakan strategi penyeleaian masalah yang telah disusun sebelumnya. (4). Menentukan solusi dari permasalahan Ditariklah suatu kesimpulan yang berupa solusi dari permasalahan tersebut. (5). Memeriksa sendiri ketepatan strategi dan kebenaran solusi yang diperoleh dari suatu masalah. Solusi yang telah diperoleh perlu diperiksa kembali kebenarannya, baik hasil maupun prosesnya. Perlu dipastikan juga semua alternatif atau kemungkinan yang terabaikan.

\section{METODE PENELITIAN}

Penelitian ini menggunakan pendekatan penelitian tindakan kelas. Setiap siklus terdiri dari beberapa tahapan, yaitu: perencanaan, tindakan, observasi, dan refleksi. Penelitian ini dilaksanakan di Program Studi Pendidikan Matematika FKIP Universitas Mataram pada semester genap tahun akademik 2016/2017. Subjek penelitian ini adalah mahasiswa Program Studi Pendidikan Matematika pada semester genap tahun akademik 2016/2017 yang menempuh mata kuliah Analisis Kompleks. Obyek penelitian meliputi seluruh proses pembelajaran.

Data penelitian diperolah dari hasil observasi yang dilakukan selama pembelajaran berlangsung dan tes. Analisis data yang digunakan adalah kuantitatif dan kualitatif. Teknik kualitatif digunakan untuk mendeskripsikan keterlaksanaan rencana tindakan, menggambarkan hambatanhambatan yang muncul dalam pelaksanaan pembelajaran dan mendeskripsikan aktivitas/partisipasi mahasiswa dalam kegiatan pembelajaran, dan kemampuan pemecahan masalah berdasarkan hasil pengamatan. Analisis kuantitatif digunakan untuk mendeskripsikan tentang efektivitas dari pembelajaran yang meliputi hasil belajar dan kemampuan pemecahan masalah mahasiswa. 


\section{HASIL DAN PEMBAHASAN}

Pembelajaran pada Siklus I membahas materi tentang Modulus Bilangan Kompleks sedangkan pembelajaran pada siklus II membahas materi tentang Bentuk Kutub Bilangan Kompleks. Setelah melalui proses perkuliahan pada siklus I dan II dengan menggunakan model pembelajaran CPS, diperoleh data aktivitas belajar mahasiswa dan hasil tes evaluasi belajar pada masing-masing siklus.

\section{Data Aktivitas Belajar Mahasiswa}

Berdasarkan hasil pengamatan melalui lembar observasi untuk aktivitas mahasiswa diperoleh data siklus I dan siklus II adalah 88,88 \% dan 91,66\%.

\section{Data Hasil Belajar Mahasiswa}

Tes siklus 1 terdiri dari 4 butir soal Tes uraian yang diberikan bersifat individu. Secara keseluruhan tes berjalan dengan lancar dan tertib. Walaupun masih ada beberapa kekurangan, tetapi selalu diingatkan oleh dosen untuk mengerjakan sendiri-sendiri. Tes berlangsung selama 100 menit. Lembar jawab mahasiswa yang telah selesai mengerjakan maupun yang belum selesai mengerjakan dikumpulkan. Hasil analisis tiap jabaran aspek pada tes siklus 1 tergambar pada Gambar 1 dan 2.

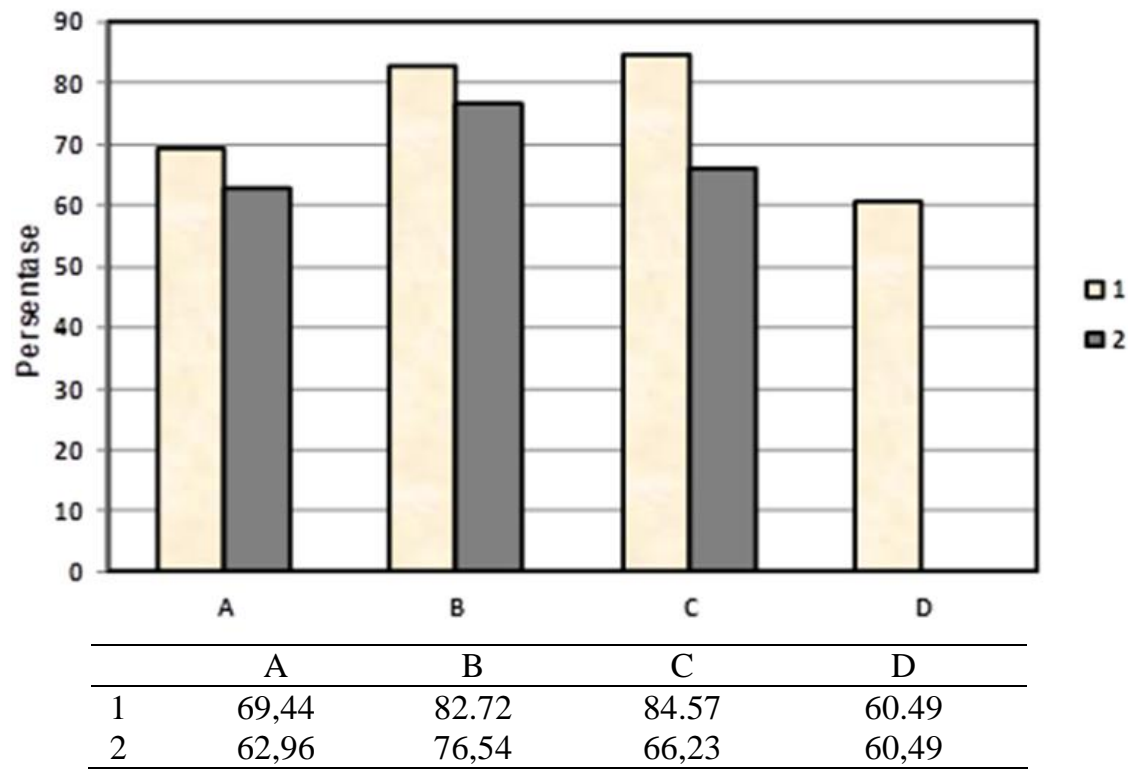

\section{Keterangan aspek:}

Gambar 1. Hasil analisis tiap jabaran aspek pada tes siklus 1

A : Kemampuan memahami masalah

1. Mengidentifikasi apa yang diketahui dari soal

2. Mengidentifikasi apa yang ditanyakan

B : Kemampuan merencanakan pemecahan masalah

1. Menggunakan rumus yang sesuai

2. Menggunakan informasi yang diketahui unttuk menyusun informasi baru

C : Kemampuan menyelesaikan masalah

1. Mensubstitusikan nilai yang diketahui dalam rumus

2. Menghitung penyelesaian masalah

D : Kemampuan menafsirkan solusi yang diperoleh

Berdasarkan Gambar 1, aspek pemecahan masalah mahasiswa yang rendah adalah aspek menafsirkan solusi yang diperoleh, mengidentifikasi apa yang ditanyakan dan aspek menghitung penyelesaian masalah sesuai rencana. Dengan melihat hasil pekerjaan mahasiswa, hal ini dikarenakan sebagian besar mahasiswa tidak menafsirkan/menyimpulkan solusi yang diperolehnya dan melakukan kesalahan pada perhitungan operasi aljabar. Pada tes siklus I, kemampuan mahasiswa memahami soal sudah baik. Kemampuan memahami soal yaitu aspek A terdiri atas: 1) mengidentifikasi apa yang diketahui dari soal dan 2) mengidentifikasi apa yang ditanyakan. Kemampuan ini meningkat pada tes siklus II.

Mahasiswa melakukan diskusi kelompok sesuai dengan langkah CPS untuk merancang penyelesaian soal kemudian melaksanakan 
penyelesaian sesuai rencana. Pada siklus I, mahasiswa kesulitan untuk menentukan rumus yang harus digunakan. Mahasiswa masih ragu-ragu dalam menyusun penyelesaian, sehingga kerap kali bertanya pada dosen atau peneliti. Setelah mendapat penjelasan, mahasiswa mampu untuk menyelesaikan soal dengan baik. Namun, kebanyakan mahasiswa enggan dalam menafsirkan atau menyimpulkan solusi yang diperolehnya. Pada siklus II, beberapa mahasiswa merasa ragu pada langkah penyelesaian masalah yang disusunnya, walaupun sebenarnya langkah tersebut sudah benar.

Kemampuan mahasiswa dalam mensubstitusi dan menyelesaikan masalah sudah baik. Mahasiswa mulai menafsirkan solusi yang diperolehnya, hanya beberapa saja yang tetap tidak melakukannya. Kemampuan dalam merancang penyelesaian soal tidak mengalami peningkatan yang cukup signifikan dari tes siklus I ke siklus II. Kemampuan merancang penyelesaian yaitu aspek $B$ terdiri atas: 1) menggunakan rumus yang sesuai dan 2) menggunakan informasi yang diketahui untuk menyusun informasi baru. Peningkatan paling besar dari tes siklus adalah kemampuan menafsirkan solusi yang diperoleh yaitu aspek D. Pada tes siklus I, banyak mahasiswa yang belum menyimpulkan solusinya.

\section{Hasil belajar pada akhir siklus II.}

Hasil analisis kemampuan pemecahan masalah pada tes siklus II ditunjuukan pada Gambar 2. Berdasarkan Gambar 2, persentase setiap aspek pemecahan masalah adalah kemampuan memahami masalah adalah $75,46 \%$. Kemampuan merencanakan penyelesaian masalah dan menyelesaiakan masalah adalah $81,79 \%$ dan $80,62 \%$. Kemampuan menafsirkan solusi adalah $87,41 \%$. Perbandingan persentase setiap aspek pemecahan masalah dari siklus I ke siklus II, terlihat pada Tabel 1 .

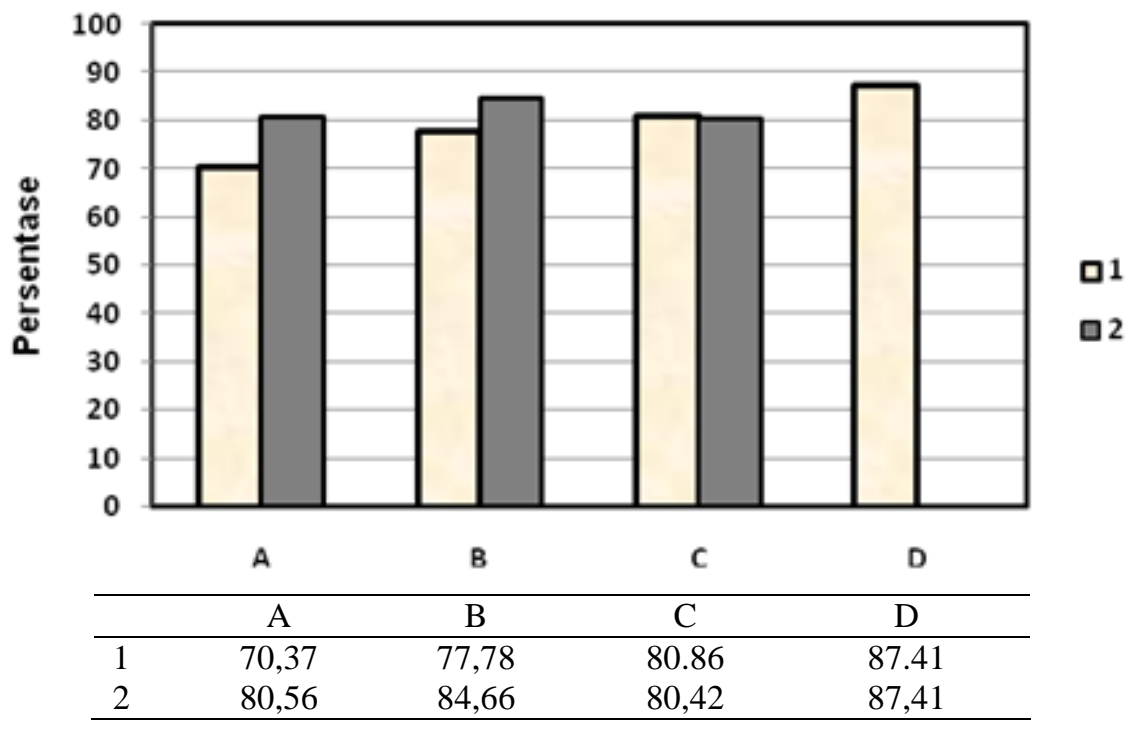

Gambar 2. Hasil analisis tiap jabaran aspek pada tes siklus II

Tabel 1. Perbandingan persentase setiap aspek pemecahan masalah dari siklus I ke siklus II

\begin{tabular}{|c|c|c|c|}
\hline \multicolumn{2}{|r|}{ Aspek } & \multirow[t]{2}{*}{ Siklus I } & \multirow[t]{2}{*}{ Siklus II } \\
\hline A & Kemampuan memahami masalah & & \\
\hline & 1. Mengidentifikasi apa yang diketahui dari soal & $69,44 \%$ & $70,37 \%$ \\
\hline & 2. Mengidentifikasi apa yang ditanyakan & $62,96 \%$ & $80,56 \%$ \\
\hline \multirow[t]{3}{*}{ B } & Kemampuan merencanakan penyelesaian masalah & & \\
\hline & 1. Menggunakan rumus yang sesuai & $82,72 \%$ & $77,78 \%$ \\
\hline & $\begin{array}{l}\text { 2. Menggunakan informasi yang diketahui untuk menyusun } \\
\text { informasi baru }\end{array}$ & $76,54 \%$ & $84,66 \%$ \\
\hline \multirow[t]{3}{*}{$\mathrm{C}$} & Kemampuan menyelesaiakan masalah & & \\
\hline & 1. Mensubstitusikan nilai yang diketahui dalam rumus & $84,57 \%$ & $80,86 \%$ \\
\hline & 2. Menghitung penyelesaian masalah & $66,23 \%$ & $80,42 \%$ \\
\hline $\mathrm{D}$ & Kemampuan menafsirkan solusi yang diperoleh & $60,49 \%$ & $87,41 \%$ \\
\hline
\end{tabular}




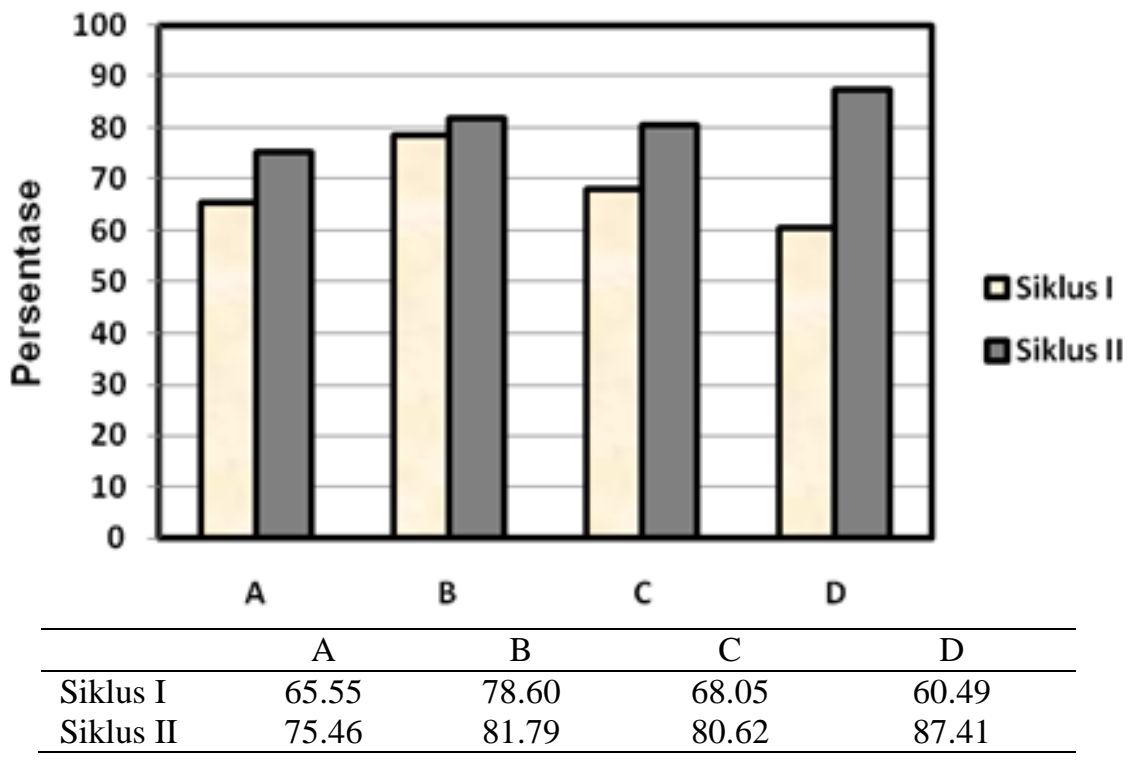

Gambar 3. Peningkatan setiap aspek pemecahan masalah

Tes diberikan kepada mahasiswa di akhir siklus 1 dan 2. Mahasiswa mengerjakan soal tes secara individu. Rata-rata nilai tes siklus I adalah 68,56 termasuk dalam kategori lebih dari cukup, sedangkan rata-rata tes siklus II adalah 83,00 termasuk dalam kategori tinggi. Rata-rata nilai meningkat sebesar 21,06 \%. Peningkatan rata-rata nilai tes menunjukkan adanya peningkatan kemampuan mahasiswa dalam memecahkan masalah.

Hasil analisis aspek pemecahan masalah pada tes akhir siklus I dan II menunujukkan peningkatan. Kemampuan memahami masalah meningkat dari $65,55 \%$ menjadi $75,46 \%$. Kemampuan merencanakan penyelesaian masalah meningkat dari $78,60 \%$ menjadi $81,79 \%$. Kemampuan menyelesaikan masalah meningkat dari $68,05 \%$ menjadi $80,62 \%$. Aspek terakhir, kemampuan menafsirkan solusi yang diperoleh meningkat dari $60,49 \%$ menjadi $87,41 \%$.

Kemampuan mahasiswa dalam memahami masalah pada siklus I dan II sudah baik. Pada siklus II, mahasiswa lebih teliti dalam mengidentifikasi apa yang ditanyakan. Kemampuan mahasiswa dalam merencanakan penyelesaian juga mengalami peningkatan, walaupun hanya sedikit. Dalam menyelesaikan masalah, mahasiswa banyak melakukan kesalahan dalam menguraikan modulus bilangan kompleks ke bentuk persamaan ellips, serta banyak mengalami kesulitan dalam menggambar ellips. Pada tes siklus I, mahasiswa masih malas untuk menafsirkan solusi yang diperolehnya. Pada siklus II, sebagian besar mahasiswa menafsirkan solusi yang diperolehnya dengan menyimpulkan jawaban.

\section{KESIMPULAN}

Berdasarkan hasil penelitian dapat disimpulkan bahwa kemampuan pemecahan masalah mahasiswa Pendidikan Matematika FKIP UNRAM dapat meningkat melalui penerapan model pembelajaran Creative Problem Solving (CPS) pada mata kuliah Analisis Kompleks. Hal tersebut nampak dari rata-rata nilai tes siklus I adalah 68,56 , sedangkan nilai rata-rata hasil tes pada siklus II adalah 83,00

\section{DAFTAR PUSTAKA}

[1] Agustinus, S. (2013). Penalaran Kuantitatif (Quantitative Reasoning) Dalam Pemecahan Masalah Matematika. In Prosiding Seminar Nasional Matematika dan Pendidikan Matematika. Jurusan Pendidikan Matematika FMIPA UNY.

[2] Gayatri, I. G. A. S., Jekti, D. S. D., \& Jufri, A. W. (2013). Efektifitas pembelajaran berbasis masalah (PBM) dan strategi kooperatif terhadap kemampuan menyelesaikan masalah dan hasil belajar kognitif biologi ditinjau dari kemampuan akademik awal siswa kelas X SMA Negeri 3 Mataram. Jurnal Pijar Mipa, 8(2).

[3] Saad,N.Ghani, S\& Rajendran N.S 2005. The Sources of Pedagogical Content Knowledge (PCK) Used by Mathematics Teacher During Instructions: A Case Study. Departement of Mathematics. Universiti Pendidikan Sultan Idris. 
J. Pijar MIPA, Vol. XIII No.1, Maret 2018: 45-50

[4] Polya, G. 1980. On Solving Mathematical Problems in High School. New Jersey: Princeton Univercity Press.

[5] Pepkin, K. 2000. Creative Problem Solving in Math [Online].

[6] Nisa, K., Jekti, D. S. D., \& Rasmi, D. A. C. (2012). Efektivitas metode pembelajaran pemecahan masalah (problem solving) dalam meningkatkan hasil belajar biologi siswa kelas X SMA Negeri 3 Mataram tahun pembelajaran 2010/2011. Jurnal Pijar Mipa, 7(2). 